\title{
Technological Innovation in the Food Industry: A Bibliometric Analysis
}

\author{
Mauricio Castillo-Vergara ${ }^{1, *}$, Issis Quispe-Fuentes ${ }^{2,3}$, Jacqueline Poblete ${ }^{2}$ \\ ${ }^{1}$ Department of Economics and Business, Faculty of Economics and Business, Universidad Alberto Hurtado \\ Erasmo Escala 1835, Santiago, Chile \\ E-mail.mhcastillo@uahurtado.cl \\ *Corresponding author
}

${ }^{2}$ Food Engineering Department, University of La Serena

Raul Bitran 1305, Box 599, La Serena, Chile

${ }^{3}$ Institute for Multidisciplinary Research in Science and Technology, University of La Serena

E-mail.iquispe@userena.cl

${ }^{2}$ Food Engineering Department, University of La Serena

Raul Bitran 1305, Box 599, La Serena, Chile

E-mail.j.pobletegalleguillos@gmail.com

cross $^{\text {ref }}$ http://dx.doi.org/10.5755/j01.ee.32.3.26000

Technological innovation is a matter of interest to governments, decision-makers, entrepreneurs, and researchers due to its impact on competitiveness, which is why publications in this field have grown exponentially. To synthesize the main research topics and highlight possible lines for future research, this work aims to develop a bibliometric analysis of technological innovation in the field of the food industry, based on the review of 1015 papers published in specialized journals. The methodology consists of analyzing bibliometric indicators of quantity and quality using the VOSviewer and SCIMat tools. The results show recognition of the different lines in which the research has organized the debate, grouping them into 12 main themes positioned on a strategic map. Furthermore, this study presents directions for future research obtained from the analysis of existing gaps. This study contributes to the literature on innovation by providing a systematization of technological innovation in the food industry.

Keywords: Bibliometric; Food Industry; Innovation; Process; Product; Technological Innovation.

\section{Introduction}

Innovation is key to economic development and growth (Tello Gamarra et al., 2019). Therefore, it is high on the agenda of most economies (Casanova et al., 2017). An important factor for the development of a company is to establish a competitive advantage (Lafuente et al., 2019), which can be achieved by developing technological innovations (Hoflinger et al., 2017).

In recent years, novel food technologies have promoted innovation in the food sector and the number of novel foods has increased considerably (Vidigal et al., 2015). Innovation has become of particular interest in the sector, even though the literature traditionally considers this industry a lowresearch-intensive sector (Bigliardi \& Galati, 2013). Nevertheless, innovations understood as novel products, processes, or services are recognized as an important tool for companies belonging to the food industry to stand out from their competitors and meet consumer expectations (Bigliardi \& Galati, 2013), and for producing a large number of innovations. However, not all companies are involved in their development (Acosta et al., 2015). Furthermore, in this context, much research has been dedicated to new technologies used in food production and processing (Vidigal et al., 2015). As the number of publications on technological innovation in the food industry continues to grow, it is interesting to examine developments in this field.
As a critical component for creating theoretical frameworks and constructing conceptual models, a bibliometric review of the literature is an excellent way to synthesize the findings and discover the areas in which the research has been developed (Snyder, 2019). A bibliometric study could facilitate the understanding of knowledge about technological innovation in the food industry. This technique allows presenting interesting results for those who are and who are not familiar with a topic (Casado-Belmonte et al., 2020).

Bibliometric studies allow a structured view of information (van Nunen et al., 2018). The application of statistical methods (Dzikowski, 2018) allows the identification of emerging areas of research (Wang, 2018; $\mathrm{Xu}$ et al., 2018), because the evaluation of the scientific quality (Dzikowski, 2018) provides a broad overview of the current state of research by topic of interest (Benton et al., 2018). While similar bibliometric studies on innovation systems have been carried out (Suominen et al., 2019), innovation adoption (van Oorschot et al., 2018) and product and process innovation in manufacturing (Marzi et al., 2017) - to our knowledge - have not been developed in the food industry, even though this sector produces an interesting number of innovations, as noted.

Following this line of reasoning and the essential economic effects generated by technological innovation, the research question that guides our scientific research is as 
follows: What are the bibliometric properties in the field of innovation in the food industry in terms of production and impact? Consequently, this work aims to provide an overview of the main research topics and reveal possible paths for future research that can be applied by the food industry in the development of novel products.

Recent research is advancing in various disciplines that offer promising new approaches that improve the understanding of the demand for functional foods, stimulating innovation and novel product development in the food industry (Mattila-Sandholm et al., 2002). The new market trend has increased demand from the food industry for new strategies, increased storage capacity, shelf life, and microbiological safety (Lin \& Zhao, 2007). The industry is looking for new opportunities to improve sustainability and enhance competitiveness with other foods. The development of foods with functional properties is a significant growth area. It is likely to continue as consumers demand more food that can help promote health and prevent disease (Scollan et al., 2006).

The food industry plays a significant role in a country's economic growth by helping people's food needs and job creation (Singh et al., 2019). Since 1995, international trade in the food and agriculture sectors has more than doubled in real terms to reach a value of USD 1.5 trillion in 2018 (FAO, 2020), equivalent to $7.5 \%$ of the total merchandise trade during 1995-2018 (FAO, 2020).

Food product development is a key research priority and a challenge for both industry and science. To achieve acceptance, development, and process, a high level of input from company, academia, and regulatory agencies is required. This is a challenging and demanding step. However, at the same time, it is essential to introduce functional food on the market (Granato et al., 2010).

This study contributes to the literature on innovation by providing a systematization of technological innovation in the food industry. An issue that, according to literature, has not been developed to date, the one we address in this work. It also contributes to presenting future research lines obtained from the gap analysis.

This paper is organized as follows. The first section focuses on the review of relevant literature. The next section presents the methodology of the study used to analyze the data. This is followed by a section on the summary of the main results and one on the discussion of the main findings. The last section concludes the study.

\section{Literature Review}

Traditional definitions of innovation include creating novel products or modifying the characteristics of some existing products, adopting new processes, entering new markets, selecting new suppliers, and making organizational changes (OECD/European Communities, 2005). Innovation is a crucial capability. Governments, policymakers, entrepreneurs, and experts expect innovation to generate economic growth and solve the most pressing problems (Glover \& Poole, 2019). Innovations have increased in all the food system segments in recent decades (Reardon et al., 2019). Since the food industry faces several changes that affect the way it operates, innovation becomes essential
(Ciliberti et al., 2016) since innovative products promote competitiveness (Cai et al., 2018).

The food sector generally has a low level of investment in research and development (R\&D), and innovation capacity could represent a force that drives companies to perform well (Carraresi et al., 2016). The evidence supports that the company's returns and growth depend on its ability to innovate (Triguero et al., 2013). Examining the link between economic performance and innovation is not a new area of research; on the contrary, this relationship is considered very strategic (Kraftova \& Kraft, 2018).

Innovation is considered one of the most critical factors to improve competitiveness, both in national and international markets (Capitanio et al., 2010). Innovation is significant in the food sector, as it faces the challenges of developing new technologies, avoiding chemical ingredients, and protecting the environment (Acosta et al., 2015). The innovation, - whether in the process or product - enables cost reduction and better response to consumer needs: quality, security, ease of use, and storage capacity (Capitanio et al., 2010). Furthermore, given the global nature of food markets, innovation may become more a necessity than an option (Triguero et al., 2013).

Technological innovation is essential for the expansion and survival of food companies in developing countries (Luo et al., 2017). Technical changes through an increased adoption of innovations are essential criteria for increasing productivity, improving food security, ensuring growth, and reducing poverty (Gebremariam \& Tesfaye, 2018). Innovations of many kinds have transformed food production, processing, distribution, and consumption systems and practices during the last seven decades since the end of World War II (Glover \& Poole, 2019). A key area of research is the role of innovations in the food industry in countering the rise in food-related problems in response to increasing obesity and diet-related chronic diseases among populations in addition to achieving sustainability (Timotijevic et al., 2019). These arguments explain the growing interest in analyzing the behavior of innovation in the agri-food sector.

\section{Methodology}

Bibliometric methods are used to help making important decisions on specialized topics (Rons, 2018). This is because it allows the monitoring and tracking of systems of scientific development (Benavides-Velasco et al., 2013) and provide useful information for researchers (AlbortMorant \& Ribeiro-Soriano, 2016; Rey-Marti et al., 2016). Following the methodology, Castillo-Vergara et al. (2018) consider the following steps: 1 . Study definition; 2. Election of the database; 3. Adjustment of search criteria; 4. Coding of recovered material; and 5. Analysis of information.

The documents' information were recovered from the Science Citation Index-Expanded, the Web of Science of Clarivate Analytics to obtain an interdisciplinary and multidisciplinary approach (Loi et al., 2016). The Web of Science (WoS) has been the main source of scientific publications (Baier-Fuentes et al., 2019), and it has been established that it has an advantage over other databases (Norris \& Oppenheim, 2007). 
Considering the work of Marzi et al. (2017), the following search string was used-TS $=$ (product innovation* OR process innovation* OR technology innovation*) — on the field WoS Topic (TS), which searches for terms in the title, abstract, keywords or keyword fields plus ${ }^{\circledR}$, and the research area of food science and technology. The scientific document types were filtered out from the articles and reviews, and a total of 1,015 documents were obtained. With the records obtained, a unique database is created in a flat file containing the complete record and cited references, including the Header section: authors, journal, keywords, country, and research field. The period of analysis ranges from 1975 to date.

In this study, activity indices were used to measure productivity, co-citation, and bibliographic linkage analysis (Zupic \& Cater, 2015). Co-citation occurs when two articles are cited independently by one or more articles, and bibliographic linkage occurs when two articles refer to a third common article in their bibliographies (Ferreira, 2018). The centrality and density measurements were used to display the detected networks (Callon et al., 1991).

Centrality (Callon et al., 1991) measures the degree of interaction of a network with respect to other networks (1), for each position $e_{k h}$ where $k$ represents a word belonging to the topic and $h$ is a keyword belonging to another topic.

Density (Callon et al., 1991) measures the internal strength of a network (2), where $i$ and $j$ are keywords belonging to the theme, and $w$ is the number of keywords (nodes) that form the theme.

Given the two measures, the research topics can be classified into four groups (Reverte \& Badillo, 2019), which are represented in a strategic diagram that describes the groups detected in a two-dimensional space (Cobo et al., 2012). Topics included the representation of the $h-$ index according to size (Alvarez-Marin et al., 2017). Association strength expresses the relationship between two words with high similarity (Van Eck \& Waltman, 2007). The method for calculating the association strength $S_{i j}$ between objects $i$ and $j$ in a map is defined as follows (3).

$C_{i j}$ denotes the similarity between objects $i$ and $j$, and $W_{i}$ and $W_{j}$ represent the times of the occurrence of objects $i$ and $j$, respectively (Zou et al., 2018).

Two tools are used for the analysis. First is the VOSviewer - a software of free access - that allows the construction of bibliometric maps (Waltman \& Van Eck, 2012), and is mainly used in the creation of a map based on the constructed data (Cobo, Lopez-Herrera, HerreraViedma, \& Herrera, 2011; Dae-Hyun, Cho, Park, \& Hong, 2016). The second is SciMAT, which allows the construction of scientific maps and the visualization of a scientific area (Cobo, Perez, Cabrerizo, Alonso, \& HerreraViedma, 2017) with strategic maps.

Based on the methodology proposed by Martinez et al . (2014) and Martinez Sanchez et al. (2014), the following configuration was established in SciMAT: word as the unit of analysis, co-occurrence analysis as the tool to build the networks, equivalence index as the measure of similarity to normalize the networks, and the single-center algorithm as the clustering algorithm to detect the themes. The analysis performed with VOS viewer considers the co-occurrence analysis of keywords.

\section{Results}

The results of the analysis showed that $70 \%$ of the documents related to the research area of food science and technology have been published after 2010. The United States of America is the country with the highest contribution (155 documents), followed by Italy with $12 \%$ and China with $11 \%$. Out of the 3,112 authors, Wim Verbeke leads the field with 13 papers, followed by Sam Saguy with eight papers and Xavier Gellynck with seven papers. The journals that have published the most papers are the British Food Journal with 104 papers, followed by Agrofood Industry Hi-Tech with 94 papers, Food Policy with 67 papers, and the Journal Trends in Food Science \& Technology with 63 papers. These last two journals stand out for being within the first quartile of the food science category (Scimago ranking, 2018).

Of the total sample, 94 records correspond to studies in the WoS economics category. According to the year in which they appeared, Table 1 shows the concepts that have marked a trend. The documents have been cited 15,129 times, and the h-index value is 58 , which indicates that at least 58 articles have received at least 58 citations. As expected, the sample follows a Pareto distribution, with 20 $\%$ of the articles receiving $79.3 \%$ of the citations (Nisonger, 2008). Further, $27.8 \%$ of the articles had not received any citations at the time of the study. Only $7.4 \%$ of the articles had not received citations at the time of analysis. Table 2 presents the ten most cited articles.

For example, from the economic area, there are 2,805 citations and the h-index value is 29 . The most cited document is by Harvey \& Pilgrim (2011), who address the new competition for land that arises from the growing and changing demand for food and start from the premise of a "trilemma of food, energy, and environment." The second most cited work is titled "Matching demand and supply in the agricultural knowledge infrastructure: Experiences with innovation intermediaries," which aims to give an overview of the different innovation intermediaries and report on their contributions and tensions that they experience with regard to their functioning (Klerkx \& Leeuwis, 2008).

Table 1

Trends Topics in Economics

\begin{tabular}{lcc}
\hline Item & Frequency & $\begin{array}{c}\text { Year of } \\
\text { appearance }\end{array}$ \\
\hline Innovation & 13 & 2012 \\
Technology & 13 & 2014 \\
Impact & 11 & 2014 \\
Productivity & 9 & 2015 \\
Adoption & 9 & 2015 \\
Determinants & 8 & 2012 \\
Farmers & 7 & 2017 \\
Governance & 6 & 2018 \\
Innovations & 6 & 2016 \\
Technology Adoption & 6 & 2018 \\
Agricultural Innovations & 6 & 2015 \\
Product & 6 & 2013 \\
Performance & 6 & 2015 \\
\hline
\end{tabular}




\begin{tabular}{lcc}
\hline Item & Frequency & $\begin{array}{c}\text { Year of } \\
\text { appearance }\end{array}$ \\
\hline Consumption & 5 & 2017 \\
Networks & 5 & 2015 \\
Information & 5 & 2017 \\
Diffusion & 5 & 2016 \\
Quality & 5 & 2011 \\
Food & 5 & 2014 \\
Demand & 5 & 2014 \\
Models & 5 & 2014 \\
R\&D & 5 & 2015 \\
Management & 5 & 2010 \\
Policy & 5 & 2013 \\
Science & 5 & 2011 \\
\hline
\end{tabular}

The documents have been cited 15,129 times, and the h-index value is 58 , which indicates that at least 58 articles have received at least 58 citations. As expected, the sample follows a Pareto distribution, with $20 \%$ of the articles receiving $79.3 \%$ of the citations (Nisonger, 2008). $27.8 \%$ of the articles had not received citations at the date of the study. In addition, only $7.4 \%$ of the articles had not received citations at the analysis date. Table 2 presents the ten most cited articles.

For example, from the economic area, citations equal 2,805 citations and an $\mathrm{H}$-index value of 29. The most cited document is by Harvey \& Pilgrim (2011), who address the new competition for land that arises from the growing and changing demand for food and starts from the premise of a 'trilemma of food, energy, and environment.'

Table 2

Most Cited Publications

\begin{tabular}{|c|c|c|c|}
\hline Title & Journal & $\begin{array}{c}\text { Year of } \\
\text { Publication }\end{array}$ & $\begin{array}{c}\text { Number } \\
\text { of } \\
\text { citations } \\
\end{array}$ \\
\hline $\begin{array}{l}\text { Innovations in beef production systems that enhance the nutritional and } \\
\text { health value of beef lipids and their relationship with meat quality }\end{array}$ & Meat Science & 2006 & 431 \\
\hline $\begin{array}{l}\text { Recent innovations in barrier technologies for plastic packaging - a } \\
\text { review }\end{array}$ & $\begin{array}{l}\text { Packaging Technology and } \\
\text { Science }\end{array}$ & 2003 & 389 \\
\hline Technological challenges for future probiotic foods & International Dairy Journal & 2002 & 330 \\
\hline $\begin{array}{l}\text { Where is MAP going? A review and future potential of modified } \\
\text { atmosphere packaging for meat }\end{array}$ & Meat Science & 2008 & 287 \\
\hline $\begin{array}{l}\text { Ultrasonic innovations in the food industry: From the laboratory to } \\
\text { commercial production }\end{array}$ & $\begin{array}{l}\text { Innovative Food Science \& } \\
\text { Emerging Technologies }\end{array}$ & 2008 & 272 \\
\hline $\begin{array}{l}\text { Consumer research in the early stages of new product development: a } \\
\text { critical review of methods and techniques }\end{array}$ & $\begin{array}{l}\text { Food Quality and } \\
\text { Preference }\end{array}$ & 2005 & 244 \\
\hline $\begin{array}{l}\text { Innovations in the development and application of edible coatings for } \\
\text { fresh and minimally processed fruits and vegetables }\end{array}$ & $\begin{array}{l}\text { Comprehensive Reviews in } \\
\text { Food Science and Food } \\
\text { Safety }\end{array}$ & 2007 & 208 \\
\hline $\begin{array}{l}\text { Comparative Sugar Recovery and Fermentation Data Following } \\
\text { Pretreatment of Poplar Wood by Leading Technologies }\end{array}$ & Biotechnology Progress & 2009 & 195 \\
\hline Probiotic Dairy Products as Functional Foods & $\begin{array}{l}\text { Comprehensive Reviews in } \\
\text { Food Science and Food } \\
\text { Safety }\end{array}$ & 2010 & 182 \\
\hline Production of omega-3 polyunsaturated fatty acid concentrates: A review & $\begin{array}{l}\text { Innovative Food Science \& } \\
\text { Emerging Technologies }\end{array}$ & 2010 & 180 \\
\hline
\end{tabular}

Co-occurrence analysis is based on the idea that a research field can be identified by the particular associations established between its keywords (Yu et al., 2018); a value equal to 15 has been used as the minimum number of cooccurrences. Co-occurrence analysis generates a network of issues and relationships. Size indicates an element's relevance, colors are used to group the elements, and distance suggests more significant co-occurrence between the keywords when it is closer (Mulet-Forteza et al., 2018). Figure 1 shows four groups. Furthermore, Table 3 shows the strength of association of the word Innovation with the concepts it is related to.
For the economy sample, an interesting phenomenon is that the different concepts-adoption, agricultural innovations, agriculture, biotechnology, collective action, consumption, demand, determinants, diffusion, farmers, food, food security, governance, impact, information, management, market, models, networks, performance, policy, product, productivity, quality, R\&D, and science and technology - in most cases, are related to using the concept of innovation or technology adoption. 


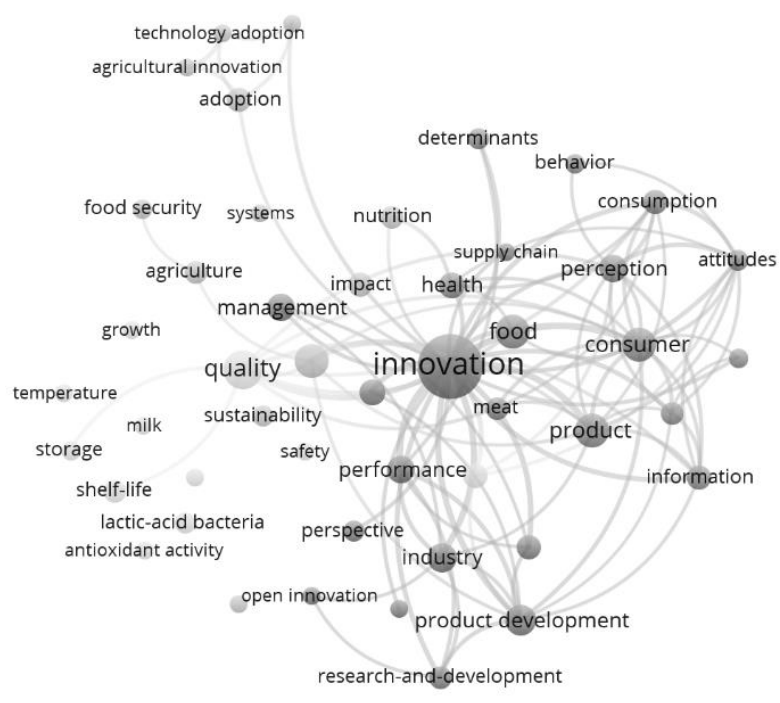

Figure 1. Network of Keywords

Table 3

Innovation Association Strength

\begin{tabular}{|c|c|c|c|c|c|c|c|}
\hline \multicolumn{8}{|c|}{ Innovation Association Strength } \\
\hline innovation & - & consumer & 22 & innovation & - & management & 8 \\
\hline innovation & - & performance & 22 & innovation & - & perspective & 8 \\
\hline innovation & - & product & 20 & innovation & - & preferences & 8 \\
\hline innovation & - & industry & 19 & innovation & - & supply chain & 7 \\
\hline innovation & - & product development & 18 & innovation & - & adoption & 6 \\
\hline innovation & - & technology & 18 & innovation & - & nutrition & 6 \\
\hline innovation & - & food industry & 15 & innovation & - & meat & 5 \\
\hline innovation & - & quality & 15 & innovation & - & safety & 5 \\
\hline innovation & - & model & 14 & innovation & - & technology adoption & 5 \\
\hline innovation & - & information & 13 & innovation & - & behavior & 4 \\
\hline innovation & - & consumption & 12 & innovation & - & biotechnology & 4 \\
\hline innovation & - & food & 12 & innovation & - & impact & 4 \\
\hline innovation & - & functional foods & 12 & innovation & - & open innovation & 4 \\
\hline innovation & - & research-and-development & 12 & innovation & - & systems & 4 \\
\hline innovation & - & acceptance & 11 & innovation & - & agriculture & 3 \\
\hline innovation & - & attitudes & 10 & innovation & - & lactic-acid bacteria & 3 \\
\hline innovation & - & health & 10 & innovation & - & growth & 2 \\
\hline innovation & - & perception & 10 & innovation & - & sustainability & 2 \\
\hline innovation & - & determinants & 9 & innovation & - & listeria-monocytogenes & 1 \\
\hline innovation & - & farmers & 8 & innovation & - & milk & 1 \\
\hline innovation & - & knowledge & 8 & innovation & - & shelf-life & 1 \\
\hline
\end{tabular}

The centrality and density analysis results show 12 themes developed when studying innovation in food science and technology. Figure 2 shows the themes graphically, positioned according to the centrality value on the horizontal axis and the density value on the vertical axis.
The themes in the upper right quadrant are attitudes, impact, and strategies. They have been presented with high density and strong centrality, and are important themes in the structuring of the field and are well developed. In the upper left quadrant, the topics present high density and low 
centrality. They are more specialized topics that are well developed, but less important in the field, such as phenolic compounds, films, starter cultures, and protein. In the lower right quadrant, the topics are presented with high centrality and low density. Although not sufficiently developed, these topics are important for research, and include systems, perspective, market, and model. The lower left quadrant presents themes that are less developed but emerging, which include "food." Figure 3 presents the network formed for "food."

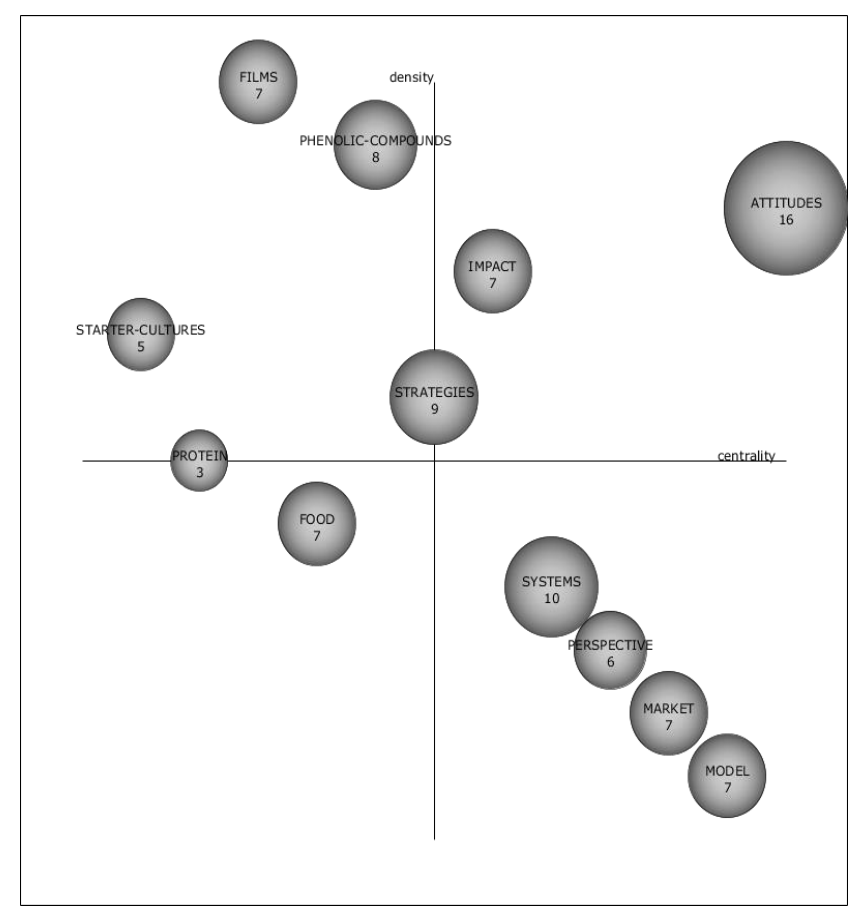

Figure 2. Themes

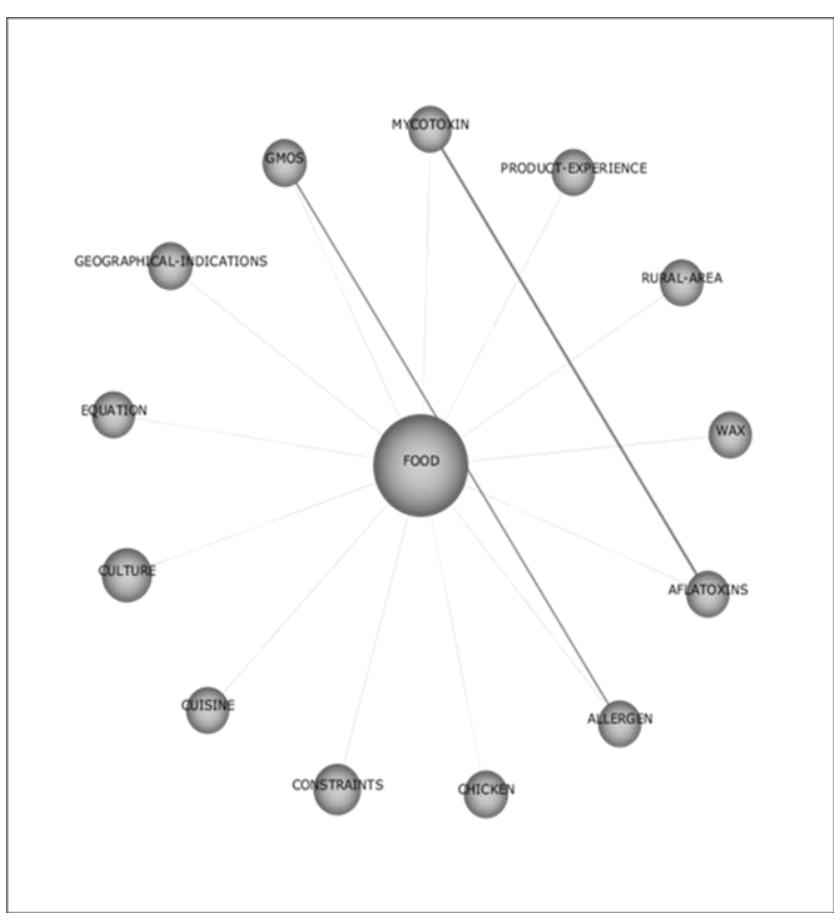

Figure 3. Emergent Themes
This network provides information on various aspects related to "food." Research directly related to "food" may be mentioned as interesting topics - such as certain mycotoxins or aflatoxins that produce harmful toxins for the consumer and are present in trace quantities in foods such as cereals, nuts, and milk, among others-since they can cause some damage in larger quantities. It also includes types of meat and various packaging or technological processes to help extend shelf life and microbiological safety. Studies are presented on allergens, which generate allergic reactions in the consumer, and the industry must declare their presence. Thus, the industry must satisfy the critical needs and develop novel products that contribute to the well-being and health.

Figure 4 shows the results according to the centrality and density of the documents from the economic themes. The development focuses on six themes, established as the driving themes and grouped under "product" and "entrepreneur." The "functional food" also shows high density and is receiving more attention. The "crop" is an essential but underdeveloped topic. Further, the "industry" and "innovation platforms" are positioned as emerging issues.

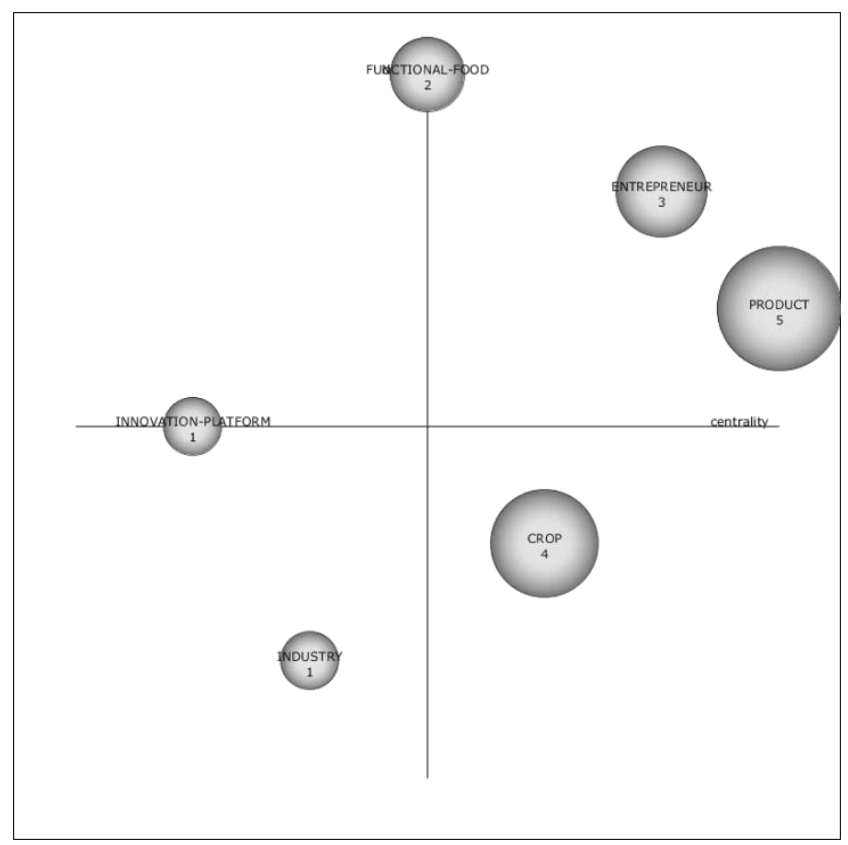

Figure 4. Economics Themes

Figure 5 shows the bibliographic link between the most productive and influential documents in the research analysis. Several groups are observed that are bibliographically linked in four networks. The first group is a network formed by European works; this includes a diverse group of works developed in Italy, Belgium, Hungary, Spain, and the United Kingdom. The works are preferably focused on developing open innovation as a strategy for the development of innovations in the industry. The second group investigates the acceptance and adoption of innovations by clients. The third group is formed by the new technologies applied in the food sector and its relationship with food neophobia. The last group studies the development of functional foods. 


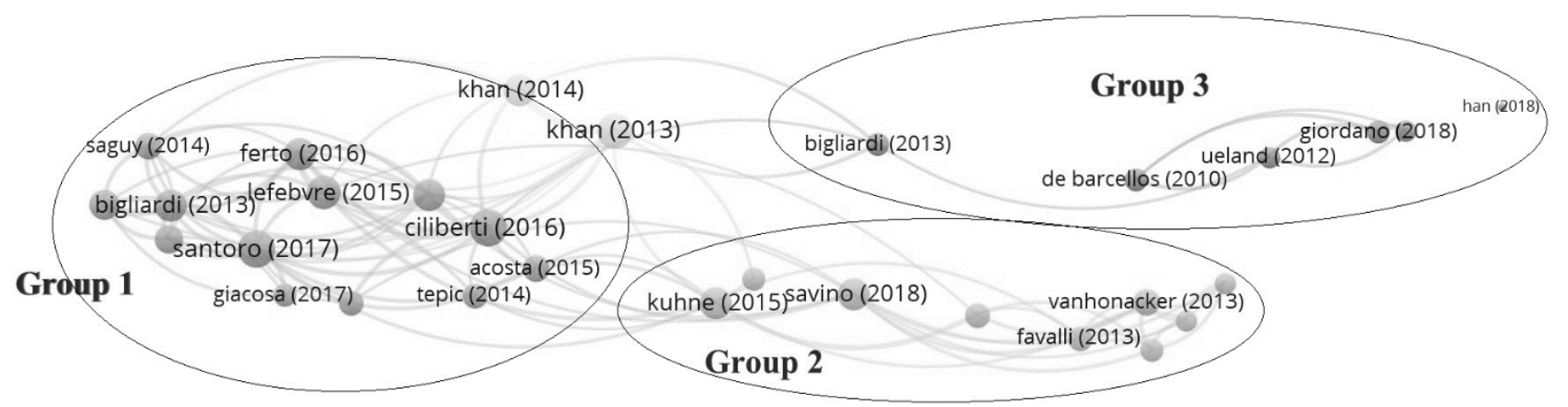

Figure 5. Bibliographic Coupling Documents

Based on the results presented in this section, it is possible to observe the importance and growth of technological innovation research in the food industry. Even though analyses from the economic point of view are less in terms of quantity, they present better quality results.

\section{Discussions}

Consumer requirements for food that is safe, healthy, quality, and convenient are increasing. In response, the food industry, supported by the research community, continues to generate new opportunities to address consumer needs (Lange \& Yves Wyser, 2003). Thus, the most cited article was Scollan et al. (2006). The authors proposed innovation in beef production systems, focusing on strategies to increase the amount of beneficial fatty acids, improving the nutritional and healthy product value. The second most cited article featured a review of the literature that focused on innovations for packaging. The authors have shown the significant development of research in new packaging technologies, presenting five main lines: (a) thin, transparent vacuum-deposited coatings; (b) new barrier polymers as discrete layers; (c) blends of barrier polymers and standard polymers; (d) organic barrier coatings; and (e) nanocomposite materials, (Lange \& Yves Wyser, 2003). The popularity of probiotics is reflected in the third article; the authors establish a research framework that allows the formulation of new types of foods fortified with encapsulated bacteria that promote health. The studies range from the selection of specific probiotics to the consideration of technical aspects of the process, sensory characteristics, and viability and stability of probiotics (Mattila-Sandholm et al., 2002). The fourth article presented a review and the future potential of modified atmosphere packaging (MAP) for meat. It is mentioned that innovations and ingenuity of packaging technology will continue to provide consumeroriented MAP, thus improving the products and making them environmentally responsive, and cost-effective. However, continued R\&D will be needed from the scientific and industrial sectors (McMillin, 2008). The fifth article presented examples of ultrasonic applications made to market products. The interest in new technologies, such as high power ultrasound is due to different applications in the food field such as emulsification, homogenization, extraction, crystallization, dehydration, low-temperature pasteurization, degassing, antifoam, enzyme activation and inactivation, particle size reduction and viscosity alteration. (Patist \& Bates, 2008).

The sixth article refers to the consumer. The authors mentioned that incorporating the "voice of the consumer" in the early stages of the novel product development process has been identified as a critical success factor. However, this step is often ignored or poorly executed due to a lack of familiarity with the available methods, the use of disciplinary terminology, and difficulty in the accessibility of papers on this subject (Kleef et al., 2005). The seventh article presents innovations in the development and application of edible coatings for fresh and minimally processed fruits and vegetables as the retail industry's main growth segment. This new market trend has increased the food industry's demands for seeking new strategies to increase storability and shelf life and enhance the microbial safety of fresh produce. Edible coatings technology has been considered as one of the potential approaches to meet this demand because these coatings can be obtained from renewable sources, including lipids, polysaccharides, and proteins, which can function as barriers to water vapor, gases. They can also be carriers of many functional ingredients, such as antimicrobial agents and antioxidants (Lin \& Zhao, 2007).

The association strength of the innovation concept is more strongly correlated with the consumer and performance concepts. This can be explained by the fact that although the food industry is considered a low researchintensive sector, product and process innovations are a tool for companies to meet consumer expectations (Bigliardi \& Galati, 2013). It is widely recognized that novel products and processes are increasingly necessary to establish a stronger foundation for competitiveness (Ciliberti et al., 2016) and promote company growth (Giacosa et al., 2017). However, innovation in the market depends mainly on consumer perceptions and characteristics (Roselli et al., 2018), such as in the packaging industry, with great dynamism, as indicated in one of the most cited articles. Innovation without an understanding of the implications for consumer perception and acceptance can be detrimental (Vanhonacker et al., 2013).

Regarding the strength of association, there are emerging areas of research, including the use of lactic acid bacteria as a driver of innovation (Alvarez-Calatayud \& Margolles, 2016; Capozzi et al., 2012), innovative processes 
for modified atmosphere packaging (Qiu et al., 2019; Wilson et al., 2019) and packaging to prolong shelf life (Nawab et al., 2018).

The first motor theme is "attitudes," which has to do with the attitudes considered for innovation development. Issues such as consumer perceptions or preferences stimulate the development of novel products. Product development considers functional foods, organic foods, and traditional foods. The second issue has to do with the "impact" of innovation. These impacts are related to the food industry's technical aspects such as fat, biomass, biocomposites, and aspects related to the economy such as regulations or markets. The third driving theme is "strategies" that allow incorporating innovation in the industry. Research on strategies deals with the development of alliances and the factors that influence the success of these alliances, and the challenges for cooperation and the inclusion of innovation platforms or programs.

Regarding important but underdeveloped issues, the first topic is "systems." This group considers conditions for developing novel products or processes in different systems such as agriculture, dairy, oils, packaging, and agribusiness. The second topic in this quadrant is "perspectives," which investigates innovation effects as a competitive advantage or value creation. The third topic is "market," which analyzes the market environment and policies to promote its growth. It also considers consumer attitudes toward innovation. The last topic in this quadrant is called "model," which has to do with the use of empirical models to test and evaluate hypotheses regarding innovation behavior.

Among the isolated topics, there are four topics that deal with the development of engineering innovations in food or bioprocesses such as "phenolic compounds," "films," "starter cultures," and "protein."

\section{Future Research Directions}

From the analysis, we have identified the direction that future research should consider. More studies are required to explore consumer attitudes toward novel and functional foods regarding innovations in the food industry. In particular, studies should be conducted in countries where research on consumer attitudes and preferences are still scarce (Santeramo et al., 2018). It is also necessary to address studies that reduce the gaps between scientific innovation, the application of nanotechnology, public policies, consumer demand, and industry development (Zhou \& Hu, 2018). Since innovations in the food industry exhibit high market failure rates due to the phenomenon known as food technology neophobia, which refers to the rejection of novel or unknown foods (Chen, 2018), more studies are needed to improve scientific evidence on communication processes and their effects.

The first information provider's role is essential in forming opinions in the food industry (Brunner et al., 2018). Attitudes and behaviors related to technological innovation that has already been addressed in different countries and cultures can also be addressed for the food industry.

$R \& D$ in packaging materials represent a viable path to lower product cost without affecting food shelf life (Han et al., 2018). The application of these innovations using functional components' bioactivity is expanding widely due to the potential benefits for consumers. However, it is important to address legislation and consumer testing (Rajan \& Gargi, 2018).

Studies are needed on innovation capacity mediated by other factors, and it would be interesting to carry out studies on non-technological innovation. For example, sensory evaluation is a fundamental tool used to evoke, measure, analyze, and interpret reactions to those characteristics of a given product perceived by the senses of sight, smell, taste, touch, and hearing during all stages of product development and processes (Yang et al., 2021).

Another line of research is related to the study of creativity and innovation performance in the food industry. Since creativity is defined as producing new and useful ideas, creative ideas can be transformed into innovations (Amabile \& Pratt, 2016). However, studies of creativity that considers the final consumer as the target audience are insufficient (Castillo-Vergara et al., 2018). The experience of this industry in incorporating consumers in the studies can present interesting results.

Finally, food science and technology should be much more linked to other sciences such as agronomy, health, socio-economics, and humanities in an interchain context for mixed food products and multifunctional foods (Abecassis $e t$ al., 2018).

\section{Conclusions}

The references in this review date from the 1970 s to 2019. Therefore, our review shows the behavior of technological innovation in the food industry over almost 50 years. Most of the works were concentrated in European countries, the United States of America, and China. More research is needed in other countries to identify whether the cultural, economic, and legal dimensions can affect innovation in the food industry. In recent years, the development of novel food products has increased as a result of the use of new technologies. The benefits are varied and include healthy, safe, nutritious, and functional foods. Where this growth is correlated with the growth of research, $70 \%$ of the publications have been made after 2010. The research has organized the debate related to acceptance of innovations, open innovation, innovation networks, innovation in traditional food products, functional foods, and new technologies, but they are still demanding more research on these topics and the techniques used. There is a more significant development of new technologies to develop novel products and processes. Emerging areas for future development are biotechnology, food packaging, and MAP as processes or results of innovation. However, we have proposed a direction for future research from the analysis performed. It is essential to carry out interdisciplinary research since there are areas that cannot be left out of the debate to ensure success in developing innovations, especially in those topics that have been studied in isolation, namely, phenolic compounds, films, proteins, or starter cultures. Economics is a science that should play a more critical role in the debate, and it was concluded that the level of citations of works in this subject area performs better than that in the area of food science.

This study has interesting results, and allows us to expand research on innovation in the food industry. 
Regarding the factors that explain why some entities are more innovative than others, it is possible to observe that it has to do with both internal and external factors. Moreover, in the development of these capacities, public policies play a central role. Considering new trends such as eco-innovation or open innovation, it becomes more relevant to continue incorporating these capacities to implement innovation.

Another promising area is the role of innovation intermediaries, especially when collaboration and knowledge transfer are crucial; the n-helix model is significant in this regard. However, in the field of food research, the debate is not deep, more research is needed on how to strengthen these relationships.

Future bibliometric research could consider different search parameters and databases than those used in this study, for example, Scopus or Google Academic.

Finally, another interesting direction would be to carry out a selection to analyze the innovation considering the economic category.

\section{References}

Abecassis, J., Cuq, B., Escudier, J., Garric, G., Kondjoyan, A., Planchot, V., Salmon, J., \& Vries, H. De. (2018). Food chains; the cradle for scienti fi c ideas and the target for technological innovations. Innovative Food Science and Emerging Technologies, 46(September 2017), 7-17. https://doi.org/10.1016/j.ifset.2017.09.011

Acosta, M., Coronado, D., \& Romero, C. (2015). Linking public support, R and D, innovation and productivity: New evidence from the Spanish food industry. Food Policy, 57, 50-61. https://doi.org/10.1016/j.foodpol.2015.09.005

Albort-Morant, G., \& Ribeiro-Soriano, D. (2016). A bibliometric analysis of international impact of business incubators. Journal of Business Research, 69(5), 1775-1779. https://doi.org/https://doi.org/10.1016/j.jbusres.2015.10.054

Alvarez-Calatayud, G., \& Margolles, A. (2016). Dual-coated lactic acid bacteria: an emerging innovative technology in the field of probiotics. Future Microbiology, 11(3), 467-475. https://doi.org/10.2217/fmb.15.150

Alvarez-Marin, A., Castillo-Vergara, M., \& Geldes-Gonzalez, C. (2017). Analisis Bibliometrico de la Realidad Aumentada y su Relacion con la Administracion de Negocios. Informacion Tecnologica, 28(4), 57-66. https://doi.org/10.40 67/S0718-07642017000400008

Amabile, T. M., \& Pratt, M. G. (2016). The dynamic componential model of creativity and innovation in organizations: Making progress, making meaning. Research in Organizational Behavior, 36, 157-183. https://doi.org/10.10 16/j.riob.2016.10.001

Baier-Fuentes, H., Merigo, J. M., Amoros, J. E., \& Gaviria-Marin, M. (2019). International entrepreneurship: a bibliometric overview. International Entrepreneurship and Management Journal, 15(2), 385-429. https://doi.org/10.1007/s11365$017-0487-\mathrm{y}$

Benavides-Velasco, C. A., Quintana-Garcia, C., \& Guzman-Parra, V. F. (2013). Trends in family business research. Small Business Economics, 40(1), 41-57. https://doi.org/10.1007/s11187-011-9362-3

Benton, D. C., Catizone, C. A., Chaudhry, H. J., DeMers, S. T., Grace, P., Hatherill, W. A., \& Monahan, M. J. (2018). Bibliometrics: A Means of Visualizing Occupational Licensure Scholarship. Journal of Nursing Regulation, 9(1), 3137. https://doi.org/10.1016/S2155-8256(18)30052-8

Bigliardi, B., \& Galati, F. (2013). Innovation trends in the food industry: The case of functional foods. Trends in Food Science and Technology, 31(2), 118-129. https://doi.org/10.1016/j.tifs.2013.03.006

Brunner, T. A., Delley, M., \& Denkel, C. (2018). Consumers' attitudes and change of attitude toward 3D-printed food. Food Quality and Preference, 68(September 2017), 389-396. https://doi.org/10.1016/j.foodqual.2017.12.010

Cai, J., Zhao, H., \& Coyte, P. C. (2018). The effect of intellectual property rights protection on the international competitiveness of the pharmaceutical manufacturing industry in China. Engineering Economics, 29(1), 62-71. https://doi.org/10.5755/j01.ee.29.1.16878

Callon, M., Courtial, J. P., \& Laville, F. (1991). Co-word analysis as a tool for describing the network of interactions between basic and technological research: The case of polymer chemsitry. Scientometrics, 22(1), 155-205. https://doi.org/10.1007/BF02019280

Capitanio, F., Coppola, A., \& Pascucci, S. (2010). Product and Process Innovation in the Italian Food Industry. Agribusiness, 26(4), 503-518. https://doi.org/10.1002/agr.20239

Capozzi, V., Russo, P., Fragasso, M., De Vita, P., Fiocco, D., \& Spano, G. (2012). Biotechnology and pasta-making: Lactic acid bacteria as a new driver of innovation. Frontiers in Microbiology, 3(MAR), 1-6. https://doi.org/10. 3389/fmicb.2012.00094

Carraresi, L., Mamaqi, X., Albisu, L. M., \& Banterle, A. (2016). Can Strategic Capabilities Affect Performance? Application of RBV to Small Food Businesses. Agribusiness an International Journal, 32(3), 416-436. https://doi.org/10.1002/agr

Casado-Belmonte, M. del P., Marin-Carrillo, G. M., Teran-Yepez, E., \& Capobianco-Uriarte, M. de las M. (2020). What is going on with the research into the internationalization of Small and Medium-Sized Enterprises (SMEs)? An intellectual structure analysis into the state-of-the-art (1990-2018). Publications, 8(1). https://doi.org/10.33 90/publications 8010011 
Casanova, L., Cornelius, P. K., \& Dutta, S. (2017). Global Innovation Competitiveness: How Emerging Economies Compare * *The contributions of Rafael Reynoso, Jordan Litner, Bruno Lanvin, Sacha Wunsch-Vincent, and Francesca Guadagno are gratefully acknowledged. In Financing Entrepreneurship and Innovation in Emerging Markets. https://doi.org/10.1016/b978-0-12-804025-6.00002-2

Castillo-Vergara, M., Alvarez-Marin, A., \& Placencio-Hidalgo, D. (2018). A bibliometric analysis of creativity in the field of business economics. Journal of Business Research, 85, 1-9. https://doi.org/10.1016/j.jbusres.2017.12.011

Chen, M. (2018). Social representations of genetically modified foods and public willingness to consume such foods in Taiwan. Journal of the Science of Food and Agriculture, 98(14), 5428-5434. https://doi.org/10.1002/jsfa.9086

Ciliberti, S., Carraresi, L., \& Broring, S. (2016). Drivers of innovation in Italy: food versus pharmaceutical industry. British Food Journal, 118(6), 1292-1316. https://doi.org/10.1108/BFJ-10-2015-0405

Cobo, Manolo, J., Lopez-Herrera, A. G., Herrera-Viedma, E., \& Herrera, F. (2011). Science mapping software tools: Review, analysis, and cooperative study among tools. Journal of the American Society for Information Science and Technology, 62(7), 1382-1402. https://doi.org/10.1002/asi.21525

Cobo, Manolo, J., Lopez-Herrera, A. G., Herrera-Viedma, E., \& Herrera, F. (2012). SciMAT: A new science mapping analysis software tool. Journal of the American Society for Information Science and Technology, 63(8), 1609-1630.

Cobo, Manuel Jesus, Perez, I. J., Cabrerizo, F. J., Alonso, S., \& Herrera-Viedma, E. (2017). Co-words Analysis of the Last Ten Years of the Fuzzy Decision Making Research Area. In Advances in Fuzzy Logic and Technology 2017 (pp. $497-$ 508). Springer. https://doi.org/10.1007/978-3-319-66830-7_45

Dae-Hyun, J., Cho, K., Park, S., \& Hong, S. (2016). Effects of knowledge diffusion on international joint research and science convergence: Multiple case studies in the fields of lithium-ion battery, fuel cell and wind power. Technological Forecasting and Social Change, 108, 15-27. https://doi.org/https://doi.org/10.1016/j.techfore.2016.03.017

Dzikowski, P. (2018). A bibliometric analysis of born global firms. Journal of Business Research, 85(November 2016), 281-294. https://doi.org/10.1016/j.jbusres.2017.12.054

FAO. (2020). El estado de los mercados de productos basicos agricolas 2020. Los mercados agricolas y el desarrollo sostenible: cadenas de valor mundiales, pequeños agricultores e innovaciones digitales. In Fao.

Ferreira, F. A. F. (2018). Mapping the field of arts-based management: Bibliographic coupling and co-citation analyses. Journal of Business Research, 85, 348-357. https://doi.org/https://doi.org/10.1016/j.jbusres.2017.03.026

Gebremariam, G., \& Tesfaye, W. (2018). The heterogeneous effect of shocks on agricultural innovations adoption: Microeconometric evidence from rural Ethiopia. Food Policy, 74(April 2016), 154-161. https://doi.org/10.10 16/j.foodpol.2017.12.010

Giacosa, E., Ferraris, A., \& Monge, F. (2017). How to strengthen the business model of an Italian family food business? British Food Journal, 119(11), 2309-2324. https://doi.org/10.1108/BFJ-03-2017-0124

Glover, D., \& Poole, N. (2019). Principles of innovation to build nutrition-sensitive food systems in South Asia. Food Policy, 82(October 2018), 63-73. https://doi.org/10.1016/j.foodpol.2018.10.010

Granato, D., Branco, G. F., \& Cruz, A. G. (2010). Probiotic Dairy Products as Functional Foods. 9(Ada 2009), 455-470. https://doi.org/10.1111/j.1541-4337.2010.00120.x

Han, J., Ruiz-Garcia, L., Qian, Jian-Ping, \&Yang, X. T. (2018). Food Packaging: A Comprehensive Review and Future Trends. Comprehensive Reviews in Food Science and Food Safety, 17, 860-877. https://doi.org/10.1111/15414337.12343

Harvey, M., \& Pilgrim, S. (2011). The new competition for land : Food, energy , and climate change q. Food Policy, 36, S40-S51. https://doi.org/10.1016/j.foodpol.2010.11.009

Hoflinger, P. J., Nagel, C., \& Sandner, P. (2017). Reputation for technological innovation: Does it actually cohere with innovative activity? Journal of Innovation \& Knowledge, 3(1), 26-39. https://doi.org/10.1016/j.jik.2017.08.002

Lange, J., \& Yves, Wyser. (2003). Recent innovations in barrier technologies for plastic packaging —a review. Packaging Technology and Science, 16(4), 149-158. https://doi.org/10.1002/pts.621

Kleef, E. Van, Trijp, H. C. M. Van, \& Luning, P. (2005). Consumer research in the early stages of new product development : a critical review of methods and techniques. 16, 181-201. https://doi.org/10.1016/j.foodqual.2004.05.012

Klerkx, L., \& Leeuwis, C. (2008). Matching demand and supply in the agricultural knowledge infrastructure : Experiences with innovation intermediaries. Food Policy, 33, 260-276. https://doi.org/10.1016/j.foodpol.2007.10.001

Kraftova, I., \& Kraft, J. (2018). The relationship between pro-innovation factors and the performance of the european union member states and their regions. Engineering Economics, 29(4), 424-433. https://doi.org/10.5755/j01.ee.29.4.19703

Lafuente, E., Leiva, J. C., Moreno-Gomez, J., \& Szerb, L. (2019). A non-parametric analysis of competitiveness efficiency: The relevance of firm size and the configuration of competitive pillars. BRQ Business Research Quarterly. https://doi.org/10.1016/j.brq.2019.02.002 
Lin, D., \& Zhao, Y. (2007). Comprehensive Reviews in Food Science and Food Safety Innovations in the Development and Application of Edible Coatings for Fresh and Minimally Processed Fruits and Vegetables. 6. https://doi.org/10.11 11/j.1541-4337.2007.00018.x

Loi, M., Castriotta, M., \& Di Guardo, M. C. (2016). The theoretical foundations of entrepreneurship education: How cocitations are shaping the field. International Small Business Journal, 34(7), 948-971. https://doi.org/10.11 $77 / 0266242615602322$

Luo, J., Guo, H., \& Jia, F. (2017). Technological innovation in agricultural co-operatives in China: Implications for agrofood innovation policies. Food Policy, 73(August), 19-33. https://doi.org/10.1016/j.foodpol.2017.09.001

Martinez, M. A., Cobo, M. J., Herrera, M., \& Herrera-Viedma, E. (2014). Analyzing the Scientific Evolution of Social Work Using Science Mapping. Research on Social Work Practice, 25(2), 257-277. https://doi.org/10.1177/10 49731514522101

Martinez Sanchez, M. A., Diaz Herrera, M., Lima Fernandez, A. I., Herrera Gomez, M., \& Herrera-Viedma, E. (2014). Un analisis bibliometrico de la produccion academica española en la categoria de Trabajo Social del "Journal Citation Report." Cuadernos de Trabajo Social, 27(2), 429-438. https://doi.org/10.5209/rev_CUTS.2014.v27.n2.44662

Marzi, G., Dabic, M., Daim, T., \& Garces, E. (2017). Product and process innovation in manufacturing firms: a 30-year bibliometric analysis. Scientometrics, 113(2), 673-704. https://doi.org/10.1007/s11192-017-2500-1

Mattila-Sandholm, T., Myllarinen, P., Crittenden, R., Mogensen, G., Fonden, R., \& Saarela, M. (2002). Technological challenges for future Probiotic foods. International Dairy Journal, 12(2-3), 173-182. https://doi.org/10.1016/S09586946(01)00099-1

McMillin, K. W. (2008). Where is MAP Going? A review and future potential of modified atmosphere packaging for meat. Meat Science, 80(1), 43-65. https://doi.org/10.1016/j.meatsci.2008.05.028

Mulet-Forteza, C., Genovart-Balaguer, J., Mauleon-Mendez, E., \& Merigo, J. M. (2018). A bibliometric research in the tourism, leisure and hospitality fields. Journal of Business Research, November, 1-9. https://doi.org/10.101 6/j.jbusres.2018.12.002

Nawab, A., Alam, F., Haq, M. A., Haider, M. S., Lutfi, Z., Kamaluddin, S., \& Hasnain, A. (2018). Innovative edible packaging from mango kernel starch for the shelf life extension of red chili powder. International Journal of Biological Macromolecules, 114, 626-631. https://doi.org/10.1016/j.ijbiomac.2018.03.148

Norris, M., \& Oppenheim, C. (2007). Comparing alternatives to the Web of Science for coverage of the social sciences' literature. Journal of Informetrics, 1(2), 161-169. https://doi.org/https://doi.org/10.1016/j.joi.2006.12.001

OECD/European Communities. (2005). Oslo manual: Guidelines for collecting and interpreting innovation data (Issue 4). Publications de l'OCDE.

Patist, A., \& Bates, D. (2008). Ultrasonic innovations in the food industry: From the laboratory to commercial production. Innovative Food Science and Emerging Technologies, 9(2), 147-154. https://doi.org/10.1016/j.ifset.2007.07.004

Qiu, L., Zhang, M., Tang, J., Adhikari, B., \& Cao, P. (2019). Innovative technologies for producing and preserving intermediate moisture foods: A review. Food Research International, 116(October 2018), 90-102. https://doi.org/10. 1016/j.foodres.2018.12.055

Rajan, S., \& Gargi, G. (2018). Emerging trends in food packaging. Nutrition \& Food Science, 48(5), 764-779. https://doi.org/10.1108/NFS-02-2018-0051

Reardon, T., Lu, L., \& Zilberman, D. (2019). Links among innovation, food system transformation, and technology adoption, with implications for food policy: Overview of a special issue. Food Policy, 83(October 2017), $285-288$. https://doi.org/10.1016/j.foodpol.2017.10.003

Reverte, C., \& Badillo, R. (2019). Alternative equity financing instruments for entrepreneurial ventures: a bibliometric analysis of research in the last three decades. Current Science, 116(6), 926-935. https://doi.org/10.18 520/cs/v116/i6/926-935

Rey-Marti, A., Ribeiro-Soriano, D., \& Palacios-Marques, D. (2016). A bibliometric analysis of social entrepreneurship. Journal of Business Research, 69(5), 1651-1655. https://doi.org/https://doi.org/10.1016/j.jbusres.2015.10.033

Rons, N. (2018). Bibliometric approximation of a scientific specialty by combining key sources, title words, authors and references. Journal of Informetrics, 12(1), 113-132. https://doi.org/https://doi.org/10.1016/j.joi.2017.12.003

Roselli, L., Cicia, G., Cavallo, C., Del Giudice, T., Carlucci, D., Clodoveo, M. L., \& De Gennaro, B. C. (2018). Consumers' willingness to buy innovative traditional food products: The case of extra-virgin olive oil extracted by ultrasound. Food Research International, 108(July 2017), 482-490. https://doi.org/10.1016/j.foodres.2018.03.070

Santeramo, F. G., Carlucci, D., Devitiis, B. De, Seccia, A., Stasi, A., Viscecchia, R., \& Nardone, G. (2018). Emerging trends in European food, diets and food industry. Food Research International, 104(October 2017), 39-47. https://doi.org/10.1016/j.foodres.2017.10.039 
Scollan, N., Hocquette, J. F., Nuernberg, K., Dannenberger, D., Richardson, I., \& Moloney, A. (2006). Innovations in beef production systems that enhance the nutritional and health value of beef lipids and their relationship with meat quality. Meat Science, 74(1), 17-33. https://doi.org/10.1016/j.meatsci.2006.05.002

Singh, R. K., Luthra, S., Mangla, S. K., \& Uniyal, S. (2019). Applications of information and communication technology for sustainable growth of SMEs in India food industry. Resources, Conservation and Recycling, 147(January), 10-18. https://doi.org/10.1016/j.resconrec.2019.04.014

Snyder, H. (2019). Literature review as a research methodology: An overview and guidelines. Journal of Business Research, 104(March), 333-339. https://doi.org/10.1016/j.jbusres.2019.07.039

Suominen, A., Seppanen, M., \& Dedehayir, O. (2019). A bibliometric review on innovation systems and ecosystems: a research agenda. European Journal of Innovation Management, 22(2), 335-360. https://doi.org/10.1108/EJIM-122017-0188

Tello Gamarra, J., Machado Leo, R., Silva Avila, A. M., \& Wendland, J. (2019). Innovation studies in Latin America: a bibliometric analysis. Journal of Technology Management \& Innovation, 13(4), 24-36. https://doi.org/10.4067/s071827242018000400024

Timotijevic, L., Khan, S. S., Raats, M., \& Braun, S. (2019). Research priority setting in food and health domain: European stakeholder beliefs about legitimacy criteria and processes. Food Policy, 83(August 2017), $116-124$. https://doi.org/10.1016/j.foodpol.2018.12.005

Triguero, A., Corcoles, D., \& Cuerva, M. (2013). Differences in Innovation Between Food and Manufacturing Firms: An Analysis of Persistence. Agribusiness an International Journal, 29(3), 273-292. https://doi.org/10.1002/agr

Van Eck, N. J., \& Waltman, L. (2007). VOS: A new method for visualizing similarities between objects. In Advances in data analysis (pp. 299-306). Springer. https://doi.org/10.1007/978-3-540-70981-7_34

van Nunen, K., Li, J., Reniers, G., \& Ponnet, K. (2018). Bibliometric analysis of safety culture research. Safety Science, 108(November 2016), 248-258. https://doi.org/10.1016/j.ssci.2017.08.011

van Oorschot, J. A. W. H., Hofman, E., \& Halman, J. I. M. (2018). A bibliometric review of the innovation adoption literature. Technological Forecasting and Social Change, 134(June), 1-21. https://doi.org/10.1016/ j.techfore.2018.04.032

Vanhonacker, F., Kuhne, B., Gellynck, X., Guerrero, L., Hersleth, M., \& Verbeke, W. (2013). Innovations in traditional foods: Impact on perceived traditional character and consumer acceptance. Food Research International, 54(2), 18281835. https://doi.org/10.1016/j.foodres.2013.10.027

Vidigal, M. C. T. R., Minim, V. P. R., Simiqueli, A. A., Souza, P. H. P., Balbino, D. F., \& Minim, L. A. (2015). Food technology neophobia and consumer attitudes toward foods produced by new and conventional technologies: A case study in Brazil. LWT - Food Science and Technology, 60(2), 832-840. https://doi.org/10.1016/j.1wt.2014.10.058

Waltman, L., \& Van Eck, N. J. (2012). A new methodology for constructing a publication-level classification system of science. Journal of the American Society for Information Science and Technology, 63(12), $2378-2392$. https://doi.org/10.1002/asi.22748

Wang, Q. (2018). A bibliometric model for identifying emerging research topics. Journal of the Association for Information Science and Technology, 69(2), 290-304. https://doi.org/10.1002/asi.23930

Wilson, M. D., Stanley, R. A., Eyles, A., \& Ross, T. (2019). Innovative processes and technologies for modified atmosphere packaging of fresh and fresh-cut fruits and vegetables. Critical Reviews in Food Science and Nutrition, 59(3), 411422. https://doi.org/10.1080/10408398.2017.1375892

Xu, X., Chen, X., Jia, F., Brown, S., Gong, Y., \& Xu, Y. (2018). Supply chain finance: A systematic literature review and bibliometric analysis. International Journal of Production Economics, 204(August), 160-173. https://doi.org/10.101 6/j.ijpe.2018.08.003

Yang, F., Guo, H., Gao, P., Yu, D., Xu, Y., Jiang, Q., Yu, P., \& Xia, W. (2021). Comparison of methodological proposal in sensory evaluation for Chinese mitten crab (Eriocheir sinensis) by data mining and sensory panel. Food Chemistry, 356(March), 129698. https://doi.org/10.1016/j.foodchem.2021.129698

Yu, D., Wang, W., Zhang, W., \& Zhang, S. (2018). A bibliometric analysis of research on multiple criteria decision making. Current Science, 114(4), 747-758. https://doi.org/10.18520/cs/v114/i04/747-758

Zhou, G., \& Hu, W. (2018). Public acceptance of and willingness-to-pay for nanofoods in the U . S . Food Control, 89, 219226. https://doi.org/10.1016/j.foodcont.2018.02.004

Zou, X., Yue, W. L., \& Vu, H. Le. (2018). Visualization and analysis of mapping knowledge domain of road safety studies. Accident Analysis \& Prevention, 118, 131-145. https://doi.org/https://doi.org/10.1016/j.aap.2018.06.010

Zupic, I., \& Cater, T. (2015). Bibliometric Methods in Management and Organization. Organizational Research Methods, 18(3), 429-472. https://doi.org/10.1177/1094428114562629 


\section{Authors' Biographies}

Castillo-Vergara Mauricio: Ph.D. in economic and business Sciences. He is an associate professor at Alberto Hurtado University, received his Ph.D. degree from Polytechnic University of Cartagena of Spain. His leading research and chairs are Entrepreneurship, Innovation, and Creativity. He has published in national and international journals such as Innovation: Organization \& Management, Journal of Business Research, Thinking Skills and Creativity, Journal of Cleaner Production, Journal of Technology \& Innovation Management. He has taught and participated in various national and international presentations, seminars, and courses.

Quispe-Fuentes Issis: Ph.D. is a Professor at La Serena University Faculty of Engineering belongs to Institute for Multidisciplinary Research in Science and Technology and is attached Food Engineering Department, University of La Serena (ULS). She received a Ph.D. degree in Food Engineering and Bioprocess from ULS in 2017 and has 10 years of experience in scientific work. She has participated in various research projects related to regional development and her research interests include Food technology and processes. She has specialized in food analytical chemistry, quantification, and extraction of bioactive compounds with biological properties.

Jacqueline Poblete: Master's Degree, she graduated from the La Serena University, and she is a Food engineer with a master's degree in food science. She is currently a doctoral student in Food and Bioprocess Engineering at the University of La Serena. Since 2017 she has served as a research assistant in the Department of Food Engineering at the University of La Serena and has participated in various external and internal research projects related to the instrumental analysis and determination of bioactive compounds. Her main research areas are the analysis of physicochemical, nutritional, and functional properties and the extraction of bioactive compounds.

The article has been reviewed.

Received in May 2020; accepted in June 2021.

This article is an Open Access article distributed under the terms and conditions of the Creative Commons Attribution 4.0 (CC BY 4.0) License (http://creativecommons.org/licenses/by/4.0/). 